\title{
An Analysis of the Characteristics and Quality of Corporate Boards of Listed Deposit Collecting Banks in Nigeria
}

\author{
Iwora Agara \\ University of KwaZulu-Natal \\ agarai@geometricpower.com \\ Lesley Stainbank \\ University of KwaZulu-Natal \\ stainbankı@ukzn.ac.za
}

\section{Doi:10.5901/mjss.2014.v5n8p198}

\begin{abstract}
The purpose of this paper is to compare the characteristics of corporate boards of Nigerian banks with the ten largest banks globally in terms of five criteria (board size, number of female board members, number of meetings per annum, age of directors, and duality of Chairman and CEO positions). These criteria have been identified as being relevant for sound corporate governance. The paper also examined whether the Nigerian corporate boards complied with the relevant national Nigerian corporate governance codes. The research methodology consisted of a content analysis of the annual reports of the selected banks. The study found significant differences between the sample of international banks and the Nigerian banks with regards to female board membership, the number of board meetings and the average age of board members. Furthermore, not all banks observed the minimum board governance codes. The regulator should require all banks to follow the Central Bank of Nigeria's code of corporate governance for banks.
\end{abstract}

Keywords: Nigeria, corporate governance, banks

\section{Introduction}

Corporate governance is described simply as the way firms are controlled and directed (Cadbury, 1992). Corporate boards are central to corporate governance practice and are an important element in the maintenance of private sector development because corporate governance seeks to not only strengthen the ability of firms to attract investment and grow, but also to make firms stronger, more efficient, and more accountable to their stakeholders (International Finance Corporation (IFC), 2010; 2013). The Cadbury Report was issued in reaction to corporate collapses such as Maxwell Communications PIc and Polly Peck International PIc in the United Kingdom (UK). Ten years later, the enactment in the United States of America (USA) of the Sarbanes-Oxley Act in 2002 was in reaction to the collapse of Enron Corporation and WorldCom (Souster, 2012). The collapse of these corporate giants was linked to the lack of sound corporate governance principles.

The board has been identified as an effective mechanism of managing agency conflicts in firms according to agency theory (Jensen and Meckling, 1976); as an effective organ in maintaining a healthy relationship between the firm and its numerous stakeholders according to the stakeholder theory of the firm (Freeman, Wicks and Parmar, 2004); and as reservoirs of resources for the development and growth of the firm according to the resource dependence theory since the boards represent to the outside world the value and worth of the organizations (Pfeffer and Salancik, 1978, in Acharya and Pollock, 2013). Therefore, when the board fails, the likelihood of the firm succeeding is extremely doubtful.

The importance of effective and trusted corporate boards to the economic development of nations cannot be overstated. Nigerian firms were not immune from the effects of the recent 2008-2009 global financial crises. In Nigeria, the banking sector has recently undergone a period of transformation and therefore this paper focuses on the review of the characteristics of the corporate boards of Nigerian deposit collecting banks in line with best practices and applicable governance codes in the Nigerian context.

The study of corporate boards continues to attract research because of the importance of corporate boards to the firm. However, studies have not been carried on the characteristics of boards of listed banks in Nigeria, such as a comparison of the characteristics of the boards of listed Nigerian banks with the boards of listed banks in developed 
economies such as Europe and the USA. A consequence of this is that Nigerian banks, although expected to execute strategies that ensure they remain relevant in the global economic renaissance, lack research evidence on to what extent their boards compare with boards of the best run banks in other developed economies. This may weaken the ability of Nigerian banks to seek foreign collaborations with potential investors and other economic developments.

Lack of attention to the boards of banks in Nigeria could affect the performance of the entire Nigerian economy which requires an efficient and effective banking system. This paper addresses this research gap by providing an insight into the characteristics of boards of listed Nigerian banks when compared to the boards of the biggest banks in the developed economies. This comparison is intended to provide information on the quality of the boards of Nigerian listed banks.

This paper addresses the following research questions:

1. To what extent do the characteristics of the corporate boards of Nigerian banks compare with the ten largest banks globally in terms of the five major criteria of board size, duality of the Chairman and Chief Executive Officer (CEO) positions, gender diversity, age of directors and number of board meetings held per year?

2. To what extent do the characteristics of the boards of listed banks in Nigeria comply with the relevant national governance codes applicable to Nigerian banks in the composition of their corporate boards?

A focus on the boards of Nigerian banks is important because of the critical roles banks play as catalysts of national economic growth and development and as vital support systems to the efforts of emerging economies in encouraging savings, stimulation of investment through the provision of credit facilities and controlling of inflation (Adeyemo, 2012).

The remainder of the paper is organised as follows: Section two discusses the background literature on corporate boards and their characteristics. Section three discusses the research methodology. Section four discusses the findings. The paper is concluded in section five together with recommendations for further research.

\section{Literature Review}

Corporate boards have become synonymous with the control and management of listed firms, characterised by management teams that are different from the owners. The separation of management from ownership of firms brings about agency conflicts, which accordingly to the agency theory proponents (Jensen and Meckling, 1976; Fama and Jensen, 1983a) arise from the human tendency to misappropriate the resources of others unless one is motivated against or deterred from such actions. The corporate board is simply a committee of selected representatives of the shareholders, investors and other stakeholders of an economic entity whose main responsibility is to provide superior supervision over the actions of employees and hired professional managers in order to ensure that actions are taken in the best interests of the stakeholders of the entity.

There are several criteria for judging the effectiveness of corporate boards such as board size, diversity, duality of Chairman/CEO positions, shareholding by board members, attendance at board meetings, gender diversity, age of directors, and nationality of members. Only literature on board size, board diversity, the duality of Chairman/CEO, and board meetings is reviewed under this section. However, the other characteristics, as they relate to the Nigerian banks, are discussed later in the paper.

\subsection{Board Size}

Literature has not identified a universal best board size. The size of boards depends on a number of factors such as size of the firm, growth opportunities, regulatory requirement, stakeholders demand, industrial demand, ownership structure and control of the firm, custom and nature of the people and environmental requirements, structure of the board, requirements by partners and funds' providers, age of boards, international reporting requirements, nature of business and associated risks, nature of responsibilities and duties of the board, depth and complexity of the issues facing the entity, and other exigencies and idiosyncrasies (Boone, Field, Karpoff, and Raheja, 2006; Council on Foundations, 2010; Dorger, 2011; Kostyuk and Koverga, 2006; De Andres, Azofra and Lopez, 2005; Lehna, Patroa, and Zhaob, 2004). There is, however, a consensus in literature that boards' size should be set so as to consider the trade-offs between the costs, such as disagreements, conflict of interest, choosing experienced directors, inadequate qualifications, dearth of resources to support the running cost of the board, and the expected benefits of a particular board size (Boone et al., 2006; Lehna et al., 2004; Ferreira, 2010).

In the Nigerian banking sector, there are two applicable codes: (1) the general governance code for listed firms issued by the Securities Exchange Commission of Nigeria (SEC - N) and (2) the industry-specific banking governance 
code issued by the Central Bank of Nigeria (CBN), which indicate the expected board size of listed firms and banks respectively. According to SEC-N (2011:11) the boards of listed firms should not be less than 5 members and should be "of sufficient size relative to the scale and complexity of the company's operations and be composed ... to ensure diversity of experience without compromising independence, compatibility, integrity and availability of members to attend meetings."

SEC-N (2011) directs that the boards of listed firms in Nigeria should be a mix of both executive and non-executive directors, headed by a chairman who should be a non-executive director. The majority of board members are expected to be non-executive directors while at least one should be an independent director. For the banking sector, the governance code issued by the CBN (2006) indicates that the board size of a listed bank should not be more than 20 members with more non-executive directors than the executive directors. Section 5.3.6 of the CBN codes for listed banks indicates that "at least two (2) non-executive board members should be independent directors (who do not represent any particular shareholder interest and hold no special business interest with the bank) appointed by the bank on merit".

The difference between the minimum number of independent directors on the boards of listed firms (one) and on the boards of listed banks (two) has allowed banks to adopt either minimum. However, taking the two codes together as applying to listed banks in Nigeria implies that if a firm is a listed company and is a bank, then such a firm should have two independent directors on its board.

Does board size matter? Ning, Davidson III and Wang (2010) state that in choosing board size, corporate decision makers should consider agency cost and resource dependence. Agency theory proponents (Jensen and Meckling, 1976; Fama and Jensen, 1983a, 1983b) argue that large boards are costly to maintain and would result in a prolonged decision making process against the quick decision response time required for firms to be competitive in complex customer-firm relationships and should be discouraged. Yermack (1996) found in his study of 452 large US industrial corporations between 1984 and 1991 that there exists an inverse relationship between board size and firm value using Tobin's Q.

On the other hand, supporters of resource dependence theory (Lückerath-Rovers, 2009; Hillman, Shropshire and Cannella Jr, 2007) argue in favour of large and diverse boards which they believe have the capacity to provide the firm with human capital to drive innovation that all entities need to have to remain relevant, provide the link between the external environment and the firm, and give legitimacy to stakeholders about the character, value and disposition of the firm. The indication in literature that board characteristics affect the effectiveness of the board which also affects the performance of the firm (De Andres et al., 2005), and with the average board size revolving between 8 and 11 members (Dorger, 2011; Kostyuk, 2006), may suggest that there is an optimal board size.

\subsection{Board Diversity}

Board diversity relates to the composition of the gender, age, skills, ethnicity, and other demographic factors of the individual members of the board. Although several attempts have been made to establish the relationship between the individual aspects of board diversity on the performance of the firm (Ujunwu, Okoyeuzu and Nwakoby, 2012; Laible, 2013; Adams, Gray and Nowland, 2011; Marimuthu and Kolandaisamy, 2009), there appears to be no consensus on whether one aspect of board diversity impacts more on the performance of the firm than another. However, literature is unanimous that board diversity in general does affect the performance of the firm and results in diverse opinions that impacts on the quality of corporate decisions (Bernardi and Threadgill, 2010; Adams and Ferreira, 2008; Dobbin and Jung, 2011; Salehnezhad and Abbasi, 2013).

The resource dependence theory supports diverse boards because of the inherent human and social capital and associated resources that diverse persons would bring into the organisation (Pfeffer and Salancik, 1978). Thus, broadening the ethnic and gender diversity of boards not only helps increase the size of the candidate pool and therefore the quality of potential board members, but also helps broaden the perspectives and experience of the whole team. The literature indicates that the number of women in corporate boards is very low ranging from $9 \%$ to $16 \%$ in the Americas and Europe except in Norway where regulation specifies an enhanced quota for female board members (Sweigart, 2012; European Commission, 2014).

The empirical evidence in literature is that inclusion of females in corporate boards provides some level of corporate legitimacy to investors, increases social and environmental responsibility, improvements in intra-board communication and overall management style leading to improved financial performance and shareholder value, increased customer and employee satisfaction, rising investor confidence, and greater market knowledge and reputation (Adams and Ferreira; 2008; Adams, Gray and Nowland, 2011; Sweigart, 2012; IFC, 2013).

There are not any regulatory provisions in any governance code in Nigeria which requires the inclusion of women in the boards of listed companies including banks. However, some passive provisions on the quality of board members 
are contained in both the CBN (2006) and the SEC-N (2011) codes. The CBN (2006) code indicates that only people of proven integrity and who are knowledgeable in business and financial matters should be on the board of listed banks while the SEC-N (2011) code states that board members of listed companies (including listed banks) should be individuals of upright personal characteristics, relevant core competence and entrepreneurial spirit with records of tangible achievements and knowledgeable in board matters. There are no requirements on age, minimum educational qualifications, number of years of experience, foreign representatives, or other demographic factors pertaining to board membership in Nigeria.

\subsection{Duality of the Positions of the Board Chairman and the Chief Executive Officer (CEO)}

There appears to be a universal concern about whether to separate the positions of the chairman of the board and the CEO or to allow one person to occupy both positions. Whereas agency theory supports the split of the two positions to avoid over-concentration of power in a single individual which may impede effective control of the firm, stakeholder theory supports the concentration of the two positions in one individual for effective command and quick decision making. In the case of the banking sector, shareholders and other corporate governance activists appear to favour the splitting of the two positions between two independent persons (Bank for International Settlements, 2010; Tribbett, 2012).

Literature is divided as to whether firms with chairman/CEO duality perform better than those that split the holding of the two positions. Empirical findings have also not been conclusive in that research findings have supported both opinions (Peng, Zhang and Li, 2007; Krause and Semadeni, 2013). The guiding criteria for corporate boards' structure have been identified to include shareholders' demands and structure, regulatory requirements, state of the firm and costbenefits trade-offs (Gabrielsson, Huse and Minichilli, 2007; Sridharan and Marsinko, 1997; Kakabadse, Kakabadse and Barratt, 2006; Thuy-Nga, 2010).

The Nigerian experience is similar. Both the CBN (2006) code for deposit collecting banks and the SEC-N (2011) code for all listed companies in Nigeria indicate that the positions of the chairman of the board and the CEO should be held by different individuals. In the case of banks in Nigeria, the CBN code rejects the creation of the position of executive vice-chairman which would allow the holder to sit as alternate chairman of the board and also as the CEO of the bank.

The Nigerian experience, according to CBN (2006), indicates that banks that had chairmen or CEOs with overbearing influence recorded serious corporate governance infractions. The occupation of position of the chairman of the board by a non-executive director not connected to the CEO is considered necessary as a check on the occupants of both offices and to improve corporate governance performance, reduce the powers of both occupants and ensure that the corporate board performs effectively and with significant independence (OECD, 2004; CBN, 2006).

\subsection{Board Meetings}

For corporate boards to carry out their responsibilities and duties effectively, members must of necessity hold meetings. In their study of 169 listed corporations from 2002 to 2007 in South Africa (SA), Ntim and Osei (2011) observe that there is a statistically significant and positive association between the frequency of corporate board meetings and corporate performance, which implies that firms whose boards meet frequently are likely to perform better than those firms whose boards do not meet regularly. This indication provides empirical evidence to the agency theory suggestion that for effective control of firms for high performance, boards should meet more regularly. Chou, Chung and Yin (2012) also found in a study of Taiwanese firms a positive relationship between board attendance by directors and the profitability of firms.

Both the SEC-N (2011) and the CBN (2006) codes indicate that regular board meetings and the attendance by board members would ensure that the board performs its oversight function and monitors management's performance effectively. All listed firms in Nigeria are expected to hold board meeting at least once every quarter in the year. The SEC$\mathrm{N}$ (2011) code indicates that every board member should attend at least two-thirds of all board meetings to qualify for renomination.

\section{Methodology}

In spite of the financial meltdown between 2008 and 2010 that affected global economic activities, especially in Europe and America, the economies of most European countries, the Americas and Asia appear to be more robust when compared to emerging economies. A review of the characteristics of the boards of some selected banks in these economic jurisdictions is considered appropriate to provide a benchmark for optimal board governance and structure of 
listed Nigerian Banks. The ten largest banks in 2012 are Deutsche Bank of Germany; the HSBC, the Royal Bank of Scotland and the Barclays Group of the UK; BNP Paribas and Credit Aricole of France; Industrial and Commercial Bank of China; Mitsubishi UFJ Financial Group of Japan; and JP Morgan Chase and the Bank of America both of the USA (Ten Largest Banks in the World, 2012). The characteristics of the boards of the banks used for this paper were those disclosed in their individual annual reports for the year ended 2012.

The Nigerian listed banks used for this study were those published on the official website of the CBN as at 20 November 2013 (CBN, 2011). However, it was only possible to access the annual reports of fifteen banks. The annual reports of fourteen banks were for the year ended 2012 while the 2011 annual report of one bank, the First Bank PIc, was substituted for 2012 because the bank changed its structure in 2012 which made it difficult to align its governance structure reported in its 2012 annual report with those of the other banks.

The data used for analysis of the characteristics of the boards of listed banks in Nigeria were derived from evidence shown in the annual reports posted on either the official websites of the individual banks, or on the websites of Investing in Africa or African Financials (www.investinginafrica.net and www.africanfinancials.com). The annual reports of the other seven banks were not available at the time of this paper. The percentage of banks studied is $68.18 \%$, which is considered sufficient to provide evidence to support the conclusions in this paper.

To answer the first research question, the relevant information disclosed in the 2012 annual reports of listed commercial banks in Nigeria was extracted and compared to the same information disclosed in the annual reports of the ten largest banks in the world. Certain of the results were subjected to the t-test to determine if there were any statistical differences in their means. The choice of 2012 is in line with the expectation of the adoption of the International Financial Reporting Standards (IFRS) by listed companies in Nigeria as approved by the Federal Government, which implies that listed firms including the commercial banks in Nigeria would put in place structures that would require financial and accounting information to be disclosed in line with IFRS and corporate governance best practices. To answer the second question, the corporate governance codes of the SEC-N and that of the CBN were used to check for the required compliance.

\section{Results}

\subsection{Characteristics of the Boards of the Ten Biggest Banks in the World}

The average asset base of the biggest ten banks in 2012 was $\$ 2.19$ trillion. The highest asset base of $\$ 2.71$ trillion was recorded by an Asian bank, while the lowest base of $\$ 2.09$ trillion was recorded by a bank in the UK. A summary of five board characteristics: type of boards, board size, board diversity (gender and age), and duality of Chairman/CEO positions and board meetings held of the biggest ten banks in the world is discussed below. (Where appropriate, figures have been rounded up in the discussion below.)

Type of board - Of the ten biggest banks, $80 \%$ operate the single-tier or unitary board structure, while $20 \%$ (mainly of Germany and China extractions) operated the two-tier structure. Germany's choice of two-tier or dual board structure is a legislative requirement (Lieder, 2002). The legal system, cost of maintaining boards and the need to reach decisions quickly at board meetings, as suggested in literature, may have influenced the choice of the tier of board to operate.

Board size - The average board size of the ten biggest banks is 16 members with the largest board size being 21 members and the smallest being 11 members. The range of board sizes of the studied banks supports the argument that there is an optimal board size in respect of each individual bank that enables boards to perform efficiently and effectively.

Board diversity - On average, $76 \%$ of the membership of the boards of the ten biggest banks were males and only $24 \%$ were females. The highest female representation was $38 \%$ on the board of BNP Paribas and the lowest was $7 \%$ on the board of the Mitsubishi UFJ Financial Group. This result confirms the sustained dominance of male members on corporate boards. However, the average female representation of $24 \%$ and the highest representation of $38 \%$ is a positive indication of a possible rise in confidence on female board membership. The average age of board members was 60 years. The youngest board member was 48 years old and the oldest board member was 73 years old. This indicates that the boards of the ten biggest banks were manned by mature men and women who may have significant experience in both board functions and industrial expertise and are thus able to effectively handle boardroom politics and dynamics.

Chairman/CEO duality - Of the ten biggest banks studied, only one bank in America (10\%) had the positions of chairman and CEO combined in one person. The other $90 \%$ of the banks have these two positions separated. The majority position that allows for separation of the positions of the chairman of the board and the CEO of the firm supports the argument of agency theory in terms of enabling the board to maintain some high level of independence to be able to 
monitor the management team.

Board meetings - The annual reports of $50 \%$ of the biggest banks neither clearly indicated board attendance nor the number of board meetings held. These may be caused by lack of adequate regulatory requirements which would have required these disclosures in the annual reports. However, information on board meetings held by five of the banks ranged from eight times to 28 times per year giving an average meetings per year of 14 times for these five banks. The HSBC recorded the lowest number of meetings (8 times) while the Deutsche Bank recorded the highest number of meetings (28 times). The absence of information on the meetings of all the banks made it difficult to establish whether the number of meetings held is country related. On a quarterly basis inferring from information disclosed by the five banks on the number of board meetings held, the evidence indicated that the ten biggest banks in the world in 2012 might have held their meetings two times per quarter.

These findings are summarised in Table 1 together with the findings relating to the characteristics of the ten biggest banks in Nigeria.

Table 1: Comparison of Board Characteristics

\begin{tabular}{|l|c|c|}
\hline & Biggest global banks $\mathbf{n = 1 0}$ & Nigerian banks $\mathbf{n = 1 5}$ \\
\hline Unitary board & $80 \%$ & $100 \%$ \\
\hline Average board size & 15.5 & 14.6 \\
\hline Largest board size & 21 & 11 \\
\hline Smallest board size & 11 & 2.33 \\
\hline Average number of females on board & 3.9 & $84 \%$ \\
\hline Average male membership & $76 \%$ & $16 \%$ \\
\hline Average female membership & $24 \%$ & $24 \%$ \\
\hline Highest female representation & $38 \%$ & $0 \%$ \\
\hline Lowest female representation & $7 \%$ & 53.69 \\
\hline Average age & 59.91 & 70 \\
\hline Oldest board member & 73 & 27 \\
\hline Youngest board member & 48 & $3 \%$ (average) and 46\% (highest) \\
\hline Foreign membership & - & $0 \%$ \\
\hline CEO/Chairman of board combined & $10 \%$ & 5.87 \\
\hline Average number of meetings (5 banks only for global) & 13.8 & 4 \\
\hline Lowest number of meetings by a bank & 8 & 8 \\
\hline Highest number of meetings by a bank & 28 & \\
\hline
\end{tabular}

\subsection{Characteristics of the Boards of the Ten Biggest Banks in Nigeria}

The results presented in Table 1 were obtained from the published annual reports of the 15 listed banks, with an average asset base of $\$ 7.72$ billion. Compared with the average asset base of the biggest ten banks in the world, the average asset base of Nigerian banks is about $0.35 \%$. This figure is abysmally low to support the drive for the level of economic development desired by Nigeria to attain the target of being among the best twenty economies in the world in the year 2020 as projected by the Nigerian government. However, the boards' governance structures of the banks exhibited high level characteristics comparable with those of the ten biggest banks in the world in 2012. (Note, where appropriate, figures have been rounded up in the discussion that follows.)

Type of board - All 15 banks operated a single tier board structure. This structure complies with the regulatory requirement for all listed firms in Nigeria and conforms to the prevailing board structure of firms in countries that operate the English legal system linked with UK. The option for a single tier board by Nigerian banks is consistent with the choice of the biggest banks in the world as at 2012. Apart from banks in China and Germany, all other banks operated a single tier board. A major benefit of a single tier board is the savings in the cost of running the boards and effectiveness in resolving board issues. A disadvantage of a single tier board structure is the ease with which board members could be influenced by management.

Board size - The average board size of listed Nigerian banks is fifteen members. The highest board number is eighteen members while the lowest is eleven board members. The average board size of Nigerian listed banks compares with that of the biggest ten banks of the developed economic jurisdictions which suggest that the benefits associated with operating an optimum board size are likely to accrue to Nigerian banks.

Board diversity - On gender, only 16\% of board members of Nigerian listed banks in 2012 were female. This percentage is disappointing when compared to the average female representation of $24 \%$ in the ten biggest banks in the 
world. The highest female board representation was three (24\%) out of 11 members while the lowest representation was zero female membership in the board of First City Monument Bank Plc. The absence of female representation in the boards of banks in Nigeria may be caused by lack of any regulatory requirement for female membership. The average age of board members was 54 years for those banks that disclosed information on age. The age of the youngest board member was 27 years while the oldest board member was 70 years old. Compared with the age distribution of the directors in the ten biggest banks worldwide, the boards of listed banks in Nigerian were manned by younger members.

Taken together, a relationship may exist between the asset base of banks and the age distribution of the member of the boards. This may indicate the need to engage more mature persons to decide on and allocate resources of a larger scale and for risk management. With regards to experience, about $92 \%$ of the board members of Nigerian listed banks had either banking or related experience or had financial and accounting analytical skills. This complies with the requirement of the CBN (2006) code that all board members must be knowledgeable in business and financial matters and that of the SEC-N (2011) code that board members should be individuals with relevant core competences and entrepreneurial spirit and be knowledgeable in board matters.

On foreign representation on boards, six banks have foreign representations in their boards. Foreign representations in the boards of Nigerian banks stood at $8 \%$ in 2012. The highest foreign board representation of $46 \%$ was recorded by Stanbic-IBTC, a predominantly South African owned bank. In all, most wholly owned Nigerian listed banks had foreign board members in their boards.

Chairman/CEO duality - All the listed banks in Nigeria had the positions of the chairman of the board and the CEO held by different persons. This indication confirms the regulatory requirement of both the CBN (2006) code and the SEC-N (2011) code. Compared to the top global ten biggest banks, the separation of the positions of the chairman and CEO is in line with the majority of the top banks where $90 \%$ of the banks adopted the separation model.

Board meetings - Both the SEC-N (2011) and the CBN (2006) codes require that the listed banks in Nigeria hold board meetings at least once every quarter, that is, at least four board meetings should be held per year. Seventy-three percent (73\%) of the banks held board meetings more than the mandatory minimum of four times in 2012. The highest number of board meetings was eight held by three banks each, while four banks complied with the minimum number of meetings of four times in 2012. The average number of board meetings held by banks in Nigeria was thus lower than the fourteen times by the ten biggest banks in the world in 2012.

Number of independent directors - The SEC-N (2011) code provides for at least one independent director on the boards of listed firms while the CBN (2006) code provides for two independent directors in the boards of listed deposit collecting banks. Evidence showed that there was a mix in the number of minimum independent directors in the boards of listed banks in Nigeria in 2012. Five banks recorded one independent director each in their boards in compliance with the provision of the SEC-N code while others complied with the provision of the CBN code of a minimum of two independent board members. On the average, listed banks in Nigeria had more than two independent directors in 2012. There was not enough information on the independent directors to determine the proportion of independent directors in the board of the ten biggest banks in the world in 2012.

To see if there were any significant differences in the means of the two different samples with regards to board characteristics, the t-test was used. These results are shown in Table 2.

Table 2: Summary of $Z$ and t-test values

\begin{tabular}{|l|c|c|c|l|}
\hline & $\begin{array}{c}\text { Difference } \\
\text { in mean }\end{array}$ & SE $_{\text {MD }}$ & $\begin{array}{c}\text { Calculated } \\
\text { Z value }\end{array}$ & \multicolumn{1}{c|}{ Remark } \\
\hline Board size & 0.90 & 1.16 & 0.78 & $\begin{array}{l}\text { Board size is not significantly different between Nigerian banks } \\
\text { and the ten biggest banks. }\end{array}$ \\
\hline $\begin{array}{l}\text { Number of females } \\
\text { on boards }\end{array}$ & 1.57 & 0.66 & 2.37 & $\begin{array}{l}\text { Female board membership is significantly different between } \\
\text { Nigerian banks and the ten biggest banks. }\end{array}$ \\
\hline $\begin{array}{l}\text { Number of board } \\
\text { meetings held per } \\
\text { annum }\end{array}$ & 7.93 & 2.38 & 3.34 & $\begin{array}{l}\text { Number of board meetings per annum is significantly different } \\
\text { between Nigerian banks and the ten biggest banks. }\end{array}$ \\
\hline Age of directors & 6.22 & 1.05 & 5.92 & $\begin{array}{l}\text { Average age of board members is significantly different } \\
\text { between Nigerian banks and the ten biggest banks. }\end{array}$ \\
\hline $\begin{array}{l}\text { Duality of chairman } \\
\text { and CEO positions }\end{array}$ & 0.10 & 0.08 & 1 & $\begin{array}{l}\text { Duality of the position of chairman and CEO is not significantly } \\
\text { different between Nigerian banks and the ten biggest banks. }\end{array}$ \\
\hline $\begin{array}{l}\text { t-test values: } \\
\text { One-sided }\end{array}$ & $\begin{array}{l}10 \% \\
1.28\end{array}$ & $\begin{array}{c}\mathbf{5} \% \\
1.64\end{array}$ \\
\hline
\end{tabular}


Using the t-test statistic (see Table 2) the evidence indicates the two aspects of board size and duality of the positions of chairman of board and CEO are not significantly different in practice by the world's ten biggest banks and Nigerian listed banks, whereas the other aspects of females in boards, board meetings held per annum, and age of directors are significantly different.

With regards to the second research question, only one bank of the fifteen banks did not have a minimum of two independent directors in compliance with CBN code, although it complied with the SEC-N code. Therefore, strictly on code observance Nigerian listed banks can be said to have complied fully with the SEC-N requirements for board membership and had over $93 \%$ compliance with CBN code.

\section{Conclusion}

Corporate boards have attracted increasing studies in legal, business and social sciences. This is because corporate boards are the fulcrum of corporate governance and the pillars that support the effective formulation of corporate strategies and performance required to ensure the optimal performance of the firm (IFC, 2013). A comparison between the characteristics of the boards of the ten largest banks in the world and the Nigerian listed banks in 2012 has provided the basis of assessment of the quality of boards of Nigerian banks.

Evidence from the annual reports of Nigerian Banks indicates that the governance structure of listed banks in Nigeria is similar to the governance structures of some of the largest banks in the world. The structures of the boards of listed banks in Nigeria, such as the separation of the position of chairman and CEO, the inclusion of women and independent directors in the board of banks are in line with suggestions put forward by both proponents of agency theory and resource dependence theory and supports empirical evidence obtained by prior studies (Lückerath-Rovers, 2009; Hillman, Shropshire and Cannella Jr, 2007).

Also, there was a high level of compliance with the requirements of the two codes that guided corporate board governance of Nigerian listed banks (SEC-N, 2011; CBN, 2006) in 2012. However, in the case where both the CBN and SEC-N codes specify different minimum independent directors some banks have adopted the minimum set out in the SEC-N code. The implication of this is that banks in Nigerian have not observed a common minimum board governance code. There is a need, therefore, for listed banks in Nigeria to be required to adopt the CBN governance code stipulations where there is conflict between the CBN and SEC-N codes.

On the issue of gender diversity, there is some indication that female board membership of banks is gaining momentum with fourteen of the fifteen banks (93.33\%) having female board members, although none of the applicable codes specifically requires the inclusion of females in corporate boards. A regulatory provision requiring listed firms in Nigeria to include female board members on their boards is recommended.

On the issue of corporate governance disclosure, it proved difficult in this study to elicit information on age, experience, educational qualifications and relationships between directors and the management team and on dealings with the banks. These disclosures, and others, should be reflected clearly and commonly by all Nigerian listed banks in their annual reports.

The high level of skills, diverse and core experience, presence of foreign board members, and the relatively low average age of board membership of listed banks in Nigeria may indicate that investors and stakeholders in the Nigerian banking sector are confident with the ability of Nigerian corporate boards of Nigerian listed banks to effectively and efficiently manage the investments entrusted to them.

This paper does have some limitations. It can be regarded as an exploratory study as it did not consider the relationship between the boards' characteristics and the performance of the banks, nor did it consider the mode of appointment of board members. Furthermore, the paper did not examine any trends in the board characteristics of the firms considered.

Further research could be undertaken to establish the statistical relationship that exists between board diversity and the performance of the banks in Nigeria to establish which aspects of board diversity impacts more or less on the performance of the firm, and whether or not firms with higher numbers of independent and female directors outperform those with lower numbers of independent and female directors in the Nigerian context.

\section{References}

Acharya, A. G., \& Pollock, T. G. (2013). Shoot for the stars? Predicting the recruitment of prestigious directors at newly public firms. Academy of Management Journal, 56 (5), 1396-1419.

Adams, R. B., \& Ferreira, D. (2008). Women in the boardroom and their impact on governance and performance. Japan: Center for 
Economic Institutions Working Paper Series, Institute of Economic Research, Hitotsubashi University.

Adams, R. B., Gray, S., \& Nowland, J. (2011). Does gender matter in the boardroom? Evidence from the market reaction to mandatory new director announcements. [Online] Available: http://ssrn.com/abstract=1953152 (November 2, 2013)

Adeyemo, K. A. (2012). Frauds in Nigerian banks: Nature, deep-seated causes, aftermaths and probable remedies. Mediterranean Journal of Social Sciences, 3(2), 279-289.

Bank for International Settlements. (2010). Principles for enhancing corporate governance. [Online] Available: http://www.bis.org/publ /bcbs176.pdf. (November 2, 2013)

Bernardi, R.A., \& Threadgill, V. H. (2010). Women directors and corporate social responsibility. Electronic Journal of Business Ethics and Organization Studies, 15(2) 15-21. [Online] Available: http://ejbo.jyu.fil (November 5, 2013)

Boone, A. L., Field, L. C., Karpoff, J. M., \& Raheja, C. G. (2006). The determinants of corporate board size and composition: An empirical analysis. [Online] Available: http://ssrn.com/abstract=605762 (November 2, 2013)

Cadbury, A. (1992). Report of the committee on the financial aspects of corporate governance. The Committee on the Financial Aspects of Corporate Governance. London: Gee and Co. Ltd.

Central Bank of Nigeria (CBN). (2006). Code of corporate governance for banks in Nigeria Post Consolidation (Effective Date: April 3, 2006). Abuja: Central Bank of Nigeria.

Central Bank of Nigeria (CBN). (2011). List of financial institutions. [Online] Available: http://www.cenbank.org/Supervision/Inst-DM.asp (March 7, 2014)

Chou, H-I., Chung, H., \& Yin, X. (2012). Attendance of board meetings and company performance: Evidence from Taiwan. [Online] Available: http://ssrn.com/abstract=2188721 (December 11, 2013)

Council on Foundations. (2010). What is the best size for your board? [Online] Available: http://www.cof.org/files/Documents /Governing_Boards/Board\%20Briefs/BoardSize.pdf. (November 2, 2013)

De Andres, P., Azofra, V., \& Lopez, F. (2005). Corporate boards in OECD countries: Size, composition, functioning and effectiveness. Corporate Governance, 13 (2), 197-210.

Dobbin, F., \& Jung, J. (2011). Corporate board gender diversity and stock performance: The competence gap or institutional investor bias? North Carolina Law Review, 89, 809-838.

Dorger, M. (2011). Size matters: Right sizing your board of directors. [Online] Available: http://dorgerconsulting.com/2011/07/20/sizematters-right-sizing-your-Board-of-directors/\#respond (November 2, 2013)

European Commission. (2014). Gender balance on corporate boards: Europe is cracking the glass ceiling. [Online] Available: http://ec.europa.eu/justice/gender-equality/index_en.htm. (March 7, 2014)

Fama, E. F., \& Jensen, M. C. (1983a) Separation of ownership and control. Journal of Law and Economics, 26, 301-325.

Fama, E. F., \& Jensen, M. C. (1983b) Agency problems and residual claims. Journal of Law \& Economics. [Online] Available: http://ssrn.com/abstract=94032 (March 7. 2014)

Ferreira, D. (2010). Board diversity. [Online) Available: http://personal.Ise.ac.uk/FERREIRD/Board\%20Diversity\%20version\%201.pdf (November 2, 2013)

Freeman, R. E., Wicks, A. C., \& Parmar. B. (2004). Stakeholder theory and "the corporate objective revisited". Organization Science, 15(3), 364-369.

Gabrielsson, J., Huse, M., \& Minichilli, A. (2007). Understanding the leadership role of the board chairperson through a team production approach. International Journal of Leadership Studies, 3 (1), 21-39.

Gevurtz, F. A. (2004). The historical and political origins of the corporate board of directors. Hofstra Law Review, 33, 89-173.

Hillman, A. J., Shropshire, C., \& Cannella Jr., A. A. (2007). Organizational predictors of women on corporate boards. Academy of Management Journal, 50 (4), 941-952.

International Finance Corporation (IFC) (2010). A corporate governance model: Building responsible boards and sustainable businesses. Washington DC: World Bank.

International Finance Corporation (IFC). (2013). Corporate governance - women on boards. [Online]. Available: http://www.ifc.org/wps/wcm/connect/e80439004f776462b9d3ff0098cb14b9/Women_on_Boards_Fact_Sheet_Apr2013.pdf?MOD $=$ AJPERES ARDS (November 12, 2013)

Jensen, M. C., \& Meckling, W. H. (1976). Theory of the firm: Managerial behaviour, agency costs and ownership structure. Journal of Financial Economics, 3, 305-360.

Kakabadse, A., Kakabadse, N. K., \& Barratt, R. (2006). Chairman and chief executive officer (CEO): That sacred and secret relationship. Journal of Management Development, 2, 134-150.

Kostyuk, A. N. (2006). Corporate board practices. Ukraine: Virtus Interpress.

Kostyuk, A. N., \& Koverga, V. (2006). Board size and composition: The main tradeoffs, Corporate Board Journal, 2 (1), 48 - 54.

Krause, R. \& Semadeni, M. (2013). Director notes: CEO-board chair separation: If it ain't broke, don't fix it. [Online] Available: http://www.conferenceBoard.org (December 12, 2013)

Laible, M-C. (2013). Gender diversity in top management and firm performance: An analysis with the IAB-Establishment panel. CAED Conference Paper, Atlanta: Institute for Employment Research.

Lehna, K., Patroa, S., \& Zhoab, M. (2004). Determinants of the size and structure of corporate boards: 1935-2000. [Online] Available: http://public.kenan-flagler.unc.edu/faculty/shivdasani/unc-duke\%20corporate\%20finance/LehnPatroZhao_Determ_Struct_Boards 0903_2004.pdf (November 2, 2013)

Lieder, $\bar{J}$. (2002). The German supervisory board on its way to professionalism. German Law Journal, 11 (2), 115 - 158. 
Lückerath-Rovers, M. (2009). Female directors on corporate boards provide legitimacy to a company: A resource dependency perspective. [Online] Available: http://ssrn.com/abstract=1411693 (December 12, 2013)

Marimuthu, M., \& Kolandaisamy, I. (2009). Ethnic and gender diversity in boards of directors and their relevance to financial performance of Malaysian companies. Journal of Sustainable Development, 2 (3), 139-148.

Ning, Y., Davidson III, W.D., \& Wang, J. (2010). Does an optimal corporate board size exist? An empirical analysis. Journal of Applied Finance, 20, 57-69.

Ntim, C. G., \& Osei, K. A. (2011). The impact of corporate board meetings on corporate performance in South Africa. African Review of Economics and Finance, 2(2), 83-103.

Organisation for Economic Cooperation and Development (OECD). (2004). OECD Principles of Corporate Governance, Paris: OECD Publications Service.

Peng, M. W., Zhang, S., \& Li, X. (2007). CEO duality and firm performance during China's institutional transitions. Management and Organization Review, 3(2), 205-225.

Pfeffer, J., \& Salancik, G. R. (1978). The external control of organizations: A resource dependence perspective. Stanford, California: Stanford Business Books.

Salehnezhad, S. H., \& Abbasi, M. (2013). The relationship between board diversity and firm performance: Empirical evidence from Iran. International Journal of Management and Humanity Sciences, 2 (3), 198-204.

Schwartz-Ziv, M., \& Weisbach, M. S. (2012). What do boards really do? Evidence from minutes of board meetings. [Online] Available: http://ssrn.com/abstract=1940433E (August 28, 2013)

Security and Exchange Commission of Nigeria (SEC-N). (2011). Code of governance for public companies in Nigeria. Abuja: SEC-N.

Souster, R. (2012). Corporate governance: the board of directors and standing committees. [Online] Available: http://www.accaglobal.com/content/dam/acca/global/PDF-students/2012s/sa_oct12-f1fab_governance.pdf (September 6, 2013)

Sridharan, U. V. \& Marsinko, A. (1997). CEO duality in the paper and forest products industry. Journal of Financial and Strategic Decisions, 10 (1), 59 - 65.

Sweigart, A. (2012). Women on board for change: The Norway model of boardroom quotas as a tool for progress in the United States and Canada. North-Western Journal of International Law \& Business, 32(4), 81A - 105A.

Ten Largest Banks in the World. (2012). [Online] Available: http://www.clicktop10.com/2013/06/top-10-largest-banks-in-the-world/ and http://www.gfmag.com/archives/160-october-2012/12015-awards-worlds-biggest-banks-2012.html\#axzz2tCB0ogiN (November 13, 2013)

Thuy-Nga, V. T. (2010). To be or not to be both CEO and board chair. [Online] Available: http://open.wmitchell.edu/facsch/184 (January $15,2014)$

Tribbett, C. (2012). Splitting the CEO and chairman roles- yes or no. [Online] Available: http://www.russellreynolds.com/sites/default /files/corporate_Board_-_splitting_the_ceo_and_chairman_roles.pdf (November 13, 2013)

Ujunwa, A., Okoyeuzu, C., \& Nwakoby, I. (2012). Corporate board diversity and firm performance: Evidence from Nigeria. Review of International Comparative Management, 13 (4), 605-620.

Yermack, D. (1996). Higher market valuation of companies with a small board of directors. Journal of Financial Economics, 40, $185-211$. 